\title{
The Effect of Art Music on Pompeo Coppini: Greatest Sculptor of Texas Monuments*
}

\author{
Valentino Belfiglio ${ }^{a}$
}

\begin{abstract}
Art music has the ability to communicate, entertain, and inspire other artists. Opera is a dramatic multimedia genre which fuses solo and choral singing with instrumental accompaniment, dance, staging, costumes, scenery, and libretto. This multimedia approach can inspire painters, sculptors, poets, writers, and other musicians in their works. Italian opera greatly inspired Pompeo Coppini-the Italian sculptor. In particular, scenes and arias by Verdi and Puccini correlate with specific tasks involved in the creation of a monument. In creating the Alamo cenotaph, Coppini often played Gioacchino Rossini's opera, "William Tell” (1829) correlating the sacrifices made by Texans for their independence at the Alamo (1836) with the sacrifices made by Swiss patriots in their independence from Austrian tyranny. This case study suggests that art music can enhance creativity and visual attention among artists of all genres.
\end{abstract}

\section{Keywords}

Art music, opera, sculpture, inspiration

The author stood in front of a bust portraiture of Gaius Julius Caesar (100-44 B.C.) during a visit to the Museo Nazionale Romano in Rome, Italy in $2001^{1}$. The sculpture is 27 inches long, 19 inches wide, and 12 inches in depth. The figure of Caesar is made of white carrara marble and weighs about 48 pounds. Caesar wears a breastplate decorated with mythical figures, perhaps to designate divine ascendance and authority. What a face! Caesar's Roman nose, pursed lips, and fixed gaze beneath his receded hairline and furloughed brow give an impression of confidence, commitment, and coolness under pressure. He seems determined and stalwart-ready for anything which might confront him on the battlefields of Gaul, Britain, or Germany. An unknown artist produced this marvelous sculpture more than two thousand years before the author was born. The author recognized that sculpture is the longest lasting, original art form. This work inspired the author to write about the Italian sculptor, Pompeo Coppini, the greatest sculptor of Texas monuments.

Pompeo Coppini (1870-1957) produced art in the form of Roman classicism. He based his artistic designs on Roman classical models. His sculptures emphasize qualities characteristically Roman in style and spirit. These qualities include: reason, objectivity, discipline, restraint, order, and harmony. Neoclassicism stimulated by renewed enthusiasm for classical civilization influenced Coppini. Spivey (2016) stated: Art and other aspects of Western Civilization "are so conditioned by the Greco-Roman legacy that we can hardly avoid using ancient Greece and Rome as exemplary" (Spivey 2016: 7). Coppini

aTexas Woman's University, USA

\section{Correspondent Author:}

Valentine Belfiglio, 11505 Sonnet Drive, Dallas, Texas 75209, USA 
especially favored Augustan classicism which emphasized the simplification of facial details, the smoothing of the skin, and the sharp edge to nose and brows (Nancy and Ramage 1991: 87). The Greco-Roman style is characterized by clarity, balance, and restraint. Coppini wrote in 1949 that: "Fine Arts are the barometer of civilization" (Coppini 1949: 380). Coppini often sang or hummed arias from operas by Giuseppe Verdi (1813-1901) or Giacomo Puccini (1858-1924) as he worked ${ }^{2}$.

\section{METHODOLOGY}

The thesis of this paper is that art music, written by master composers can inspire, enlighten, and unleash the creativity of masters of other art forms, such as poetry, painting, and sculpture. This is particularly true when artists live and work in the same time period. Music accomplishes this by stimulating the auditory cortex, cerebrum, especially the dorsolateral frontal cortex and other parts of the brain, thereby affecting emotions and mood. This paper provides a configurative-ideographic case study that examines the inspiration of operatic arias by Verdi and Puccini on Coppini's sculptural creations. The three men produced their artistic creations during the Romantic Period (1828-1900) (Pen 1992: 212-213). The opera verismo of Puccini and Verdi presented plots based on realism. They portrayed dramatic subjects and constructed a unified and seamless style in which arias, recitatives, choruses, and orchestra were as a continuum rather than as a series of separate unrelated pieces (Pen 1992: 229). This seamless and unified style can be seen in Coppini's sculptures. For example, he used ashlar - a technique in which stone blocks were hewn to an accurate square and cut to a smooth facing.

\section{BIOGRAPHICAL SKETCH}

Pompeo Luigi Coppini was born in Moglia, in the province of Mantua (Lombardy), Italy, on May 19,
1870. He was the son of Giovanni and Leandra (Raffa) Coppini (Falk 1985: 130). Coppini's father was a musician. In 1871, Giovanni moved his family to Florence, one of the richest centers of Renaissance art in the world. High Renaissance Art attained the ideal of harmony and balance within the framework of classical realism. Pompeo enrolled as an engineering student in Florence, but left to enter the Accademia dell' Arte del Disegno (Art Academy of Design) under Professor Augusto Rivalta (1838-1925). Rivalta was a renowned realist sculptor who designed many memorial monuments to heroes of the Risorgimento (Resasco and Camposanto 1922: 64). Rivalta's realism featured fidelity to natural appearances without slavish attention to minute details. Coppini completed an eight-year program in art in three years, and graduated summa cum laude in 1889 (Marquis 1940).

Coppini served in the Italian army between 1889 and 1892, after which he worked in various occupations, with intervals of sculpting. Coppini opened a studio in Florence where he sculpted busts of local celebrities. On March 5, 1896, Coppini joined the millions of Italians who migrated to the United States between 1865 and 1922 in order to improve their fortunes. He secured a position at the Eden Musee in New York City, where he created four large waxworks at this amusement park. On February 27, 1898, he married his model Elizabeth de Barbieri of New Haven, Connecticut. Coppini then began a series of major works throughout the United States. In 1898, he sculpted the statutory groups for the Trans-Mississippi Exposition held at Omaha, Nebraska. A year later, he began similar work for the Pan-American Export Exposition in Philadelphia, Pennsylvania. He then conducted an art school in New York City (White 1965). Coppini became an American citizen in 1902.

\section{COPPINI MOVES TO TEXAS}

In 1900, Texas was primarily a state of small towns 
that are rural areas. The population of 3,048,710 was made up of farmers, ranchers, and small businesses ${ }^{3}$. Then on January 10, 1901, engineers discovered petroleum at Spindletop, near Beaumont. As the industrial, oil-using society expanded, so did Texas production and wealth (Fehrenbach 1985: 667). At this time, Coppini's potential as a great sculptor was coming to fruition. In November, he accepted an invitation from his friend, the German-born sculptor Frank Teich (1856-1939) to assist him in constructing the Confederate monument on the State Capitol grounds in Austin, Texas. Teich was a master of sculpturing in granite, and Coppini created five bronze statues as part of that project (Biesele 1996).

Coppini was commissioned to design a monument to Rufus C. Burleson, President of Baylor University, in 1902. The statue is a remarkable work of art. Coppini's next important work was an equestrian statue honoring Terry's Texas Rangers on the State Capitol grounds. Terry's Texas Rangers were the 8th Texas Cavalry Regiment who fought heroically for the Confederate States Army assembled by Colonel Benjamin Terry in 1861. The monument was widely acclaimed after its completion in 1907 (Belfiglio 1995: 160).

In 1917, Coppini sculptured the Charles Noyes cowboy equestrian group at Ballinger, Texas, and a memorial to Governor Sul Ross on the Texas A\&M Campus. His memorial to Judge Robert E. Baylor, on the campus of Baylor University is extraordinary. It is supported on a continuous ring type footing, pier, and cap-reinforced concrete foundation, designed as a rigid frame. The platform is paved with a honed curb and axed slabs supporting five blocks of pink granite, upon which rests the seated bronze portraiture cast by Coppini. The sand-blown inscription bearing Baylor's name appears on the rear block and two flanking blocks (Forrester-O’Brien 1935: 250-253). Baylor is seated in the open Lincolnesque position, leaning slightly forward to give an impression of interest in the observer.
Coppini continued to expand upon his genius as a sculptor. He executed the monument for Sam Houston's tomb in Huntsville, the Texas Heroes memorial at Gonzales, and a series of six bronze statues in the Texas Hall of Heroes at Dallas. Notable among Coppini's works is a colossal fountain group, which he dedicated at the University of Texas in 1933 as a World War I memorial. Other major works in Texas include: the U.S. Senator John H. Reagan memorial at Palestine, the Stephen F. Austin and Joana Troutman statues at Austin, the James D. Richardson statue at Dallas, a Confederate Memorial at Victoria, a Confederate Memorial fountain at Corpus Christi, and many others. Coppini also designed the allegorical bronze doors and the Scottish Rite Cathedral at San Antonio, as well as the American Legion Texas Centennial half-dollar (Marquis 1940). One could become completely exhausted travelling around the State of Texas in search of Coppini's marvelous monuments. $\mathrm{He}$ completed nearly 70 public monuments in various cities throughout the United States, and others in various parts of Italy and Mexico (White 1965).

In 1932, an amendment to the Texas constitution authorized a centennial celebration and instructed the Texas state legislature to make budgetary provisions for the centennial. Texas Independence Day is the celebration of the adoption of the Texas Declaration of Independence from Mexico on March 2, 1836. Governor Miriam A. Ferguson appointed a Texas Centennial Commission in June 1934. The Texas Legislature and the U.S. Congress each appropriated three million dollars for the Texas independence celebration. A Commission of Control worked with an Advisory Board of Texas Historians, the Work Projects Administration, and the Texas Highway Department to erect buildings monuments, statues, and grave markers. The Centennial Commission allocated $\$ 100,000$ in federal and state funds for the construction of a cenotaph for the heroes of the Alamo (Dallas Morning News 1936). The Alamo was a 
heavily fortified walled mission building in San Antonio, Texas besieged by 7,000 Mexican troops under the command of General Santa Anna from February 23 to March 6, 1836. Almost all of the 200 defenders died in the battle. Its effect was to stimulate morale under the cry "Remember the Alamo!" (Fehrenbach 1985: 205-215).

Coppini loved Texas, especially San Antonio for its history and culture. He long desired to make a monument in front of the Alamo. Coppini wrote: "My fight to secure the contract to build that memorial has been the hardest of my whole life" (Coppini 1949: 337, 340). In late December 1936, Coppini received a letter from his friend, Harry Hertzberg, former Texas state senator. Hertzberg informed him that several renowned New York sculptors were in San Antonio for interviews with John Singleton about the cenotaph. The sculptors were Paul Manship, Lee Lawrie, and Gaetano Cecere. Singleton was the Chair of the Centennial Division of the State Board of Control. John Gutzon Borglum (1867-1941), a friend of Southwestern historian, J. Frank Dobie, also petitioned to create the cenotaph (Newsweek 1940: 41).

Many thought that Borglum would receive the commission. He was associated with the creation of the Mount Rushmore National Memorial in South Dakota in 1927. Coppini was 67 at the beginning of 1937, and was pessimistic of receiving the commission of creating the cenotaph. Coppini wrote: It was a horrible period of bad health and almost superhuman efforts, a period of worries, disappointments, mistreatment, battling against what did look, at the time, as an unavoidable defeat (Coppini 1949: 367). He often sang "con onor muore" (to die with honor) from Puccini's "Madam Butterfly" during this depressing period.

Then on January 8, 1937, Coppini received a letter from the State Board of Control, asking him to submit sketches and ideas for the project. Coppini gathered his materials and met with Carleton Adams, architect and designer for the project on January 11 . He and Adams visited the State Board of Control in Austin several times. On March 3, Claude Teer, chairman of the board, told Coppini that he was appointed as the sculptor of the cenotaph. He is known to have sung the "Triumphal Procession" from Verdi's opera "Aida" often after that moment (Coppini 1949: 368-369, 376-377).

The Board accepted Coppini's bozzetto (miniature model) of the project, and he and his group of assistants worked tirelessly on the monument for the next two and a half years. They often sang "coro di zingari" (Anvil Chorus) from Verdi's "II Trovatore" as they chiseled at the cenotaph. Coppini applied the finishing touches that only a master could provide while he hummed Verdi's "per me ora fatale" (for my fatal hour), from that same opera. By December 1937, he fashioned the armature for the figure on the shaft. He explained:

"My prime difficulty came in the building of a mobile scaffold that I could raise and lower with ease, at will... I had nothing more than a couple of hooks I placed on the ceiling crossbeam which we doubled in strength for the very purpose" (Coppini 1949: 377, 379-380).

By October 15, 1938, Coppini finished the east panel of the cenotaph. He made plaster models for the statues that he would carve in Georgia marble. Coppini and his wife drove to Nelson, Georgia to select the finest blocks of marble and the work continued. Coppini molded the core of the shaft of the cenotaph. Then he and his chief assistant, Waldine Amanda Tauch (1892-1986), tarred the inside of the marble to protect it from dampness. Tauch was a distinguished sculptress who created several major sculptures throughout the United States (Curlee 1996). Coppini and his crew worked almost nonstop during the daytime into the evening hours. He completed the monument on September 21, 1939. He sang "E lucevan le stele" (and the stars were shining) from Puccini’s opera, "Tosca”, several times. 
On November 19, 1939, the New York Times reported:

This Winter the historic Alamo will have new interest for the visitors who walk through its hallowed gates... a $\$ 100,000$ cenotaph of gray marble and pink granite to the Alamo dead has just been placed outside the walls, where it stands as though on guard duty before a shrine... The sculptural parts were conceived and executed by Pompeo Coppini ${ }^{4}$.

San Antonio Mayor Maury Maverick decided to dedicate the monument on Armistice Day, November $11,1940^{5}$. Workers covered the cenotaph with cut flowers and decorative plants for the dedication ceremony. Spectators sat in chairs in front of the memorial, and listened to an invocation and short speeches by Mayor Maverick and Maestro Coppini. A local high school band played patriotic music including the state song of Texas, "Texas, Our Texas". Part of the refrain for the song includes: "Emblem of freedom! It sets our hearts aglow, with thoughts of San Jacinto and glorious Alamo" (Coppini 1949: 385).

The memorial, constructed of Georgia gray marble, rests upon a slab base of Texas pink granite. The great shaft rises 60 feet from its base, 40 feet in length, and 12 feet in width. The theme of the cenotaph is the "Spirit of Sacrifice", represented on the south and main face of the shaft by a magnificent idealistic figure rising 23 feet from the long, sloping capstone emblematic of the tomb. This monolithic slab, 20 feet in length, bears appropriate ornamental tracery. The east and west ledges are decorated with background panels of eight figures in low relief glorifying all of the men who died at the Alamo (Schoen 1938: 84; Burson N.d.: 1-39).

Before the east panel of the cenotaph stand gallant portrait statues of James Bowie and James Bonham; before the west panel, inspiring images of William Travis and David Crockett. On the north side appears a likeness of the Roman goddess Libertas (Liberty), holding the shields of Texas and the United States. An inscription on the monument reads:

ERECTED IN MEMORY OF

THE HEROES WHO SACRIFICED THEIR LIVES AT THE

ALAMO, MARCH 6, 1836

IN THE DEFENSE OF TEXAS

"THEY CHOSE NEVER TO SURRENDER NOR

RETREAT, THESE BRAVE HEARTS

WITH FLAG STILL PROUDLY WAVING PERISHED IN THE FLAMES OF

IMMORTALITY THAT THEIR HIGH

SCARIFICE MIGHT LEAD TO THE FOUNDING

OF THIS TEXAS" (Schoen 1938: 85)

The Alamo cenotaph passionately asserts the unity of the human body, mind, and spirit. It can be admired from the point of view of the body-those well-formed statues of war heroes and the beautiful feminine figure, cast in the style of classical realism. It can also be looked at from the standpoint of the mind - a great embodiment of intellectual creativity and psychic energy. However, the awesome, rising idealistic effigy and theme of the monument "Spirit of Sacrifice" clearly demonstrate that Coppini was chiefly concerned with the human spirit.

When Coppini finished the Alamo monument, he was totally exhausted. He wrote: "After the Cenotaph, I fell in a complete state of lethargy" (Coppini 1949: 386). Administrative officials at Trinity University in San Antonio decided to offer Coppini chairmanship of the Department of Art of that university. "I was offered the very chance I had been for so long: to dedicate the sunset days of my life to teaching and being of service to the... youths of our country" (Coppini 1949: 387), Coppini accepted the appointment and served both as a professor and chair from 1943 to 1945. Unfortunately for Coppini, Twentieth Century art was displacing the art of the Romantic Period at this time. The Twentieth Century was marked by a plurality of styles and approaches that, within a brief span of time, were disseminated, assimilated, and often abandoned. This contrasted 
with the universal aesthetic principles and styles of the Romantic Period (Pen 1992: 234-235). Coppini vehemently disliked abstract expressionism in all of its forms. He called it a "modern debauchery of art" (The Rotarian 1939). To him, expressionism, surrealism, cubism, and other forms of kitsch were novelties masquerading as art.

Coppini resigned from his university position and painted mainly for diversion and relaxation. He still enjoyed listening to arias sung by Enrico Caruso (1873-1921), Adelina Patti (1843-1927), and other singers through the use of his phonograph. Pompeo Coppini died in a San Antonio hospital on September 26, 1957. He was buried in Sunset Memorial Park in a crypt of his own design (The Dallas Morning News 1957).

\section{CONCLUSIONS}

Operatic arias by Verdi and Puccini inspired, enlightened, and helped to unleash the creativity of Coppini as a great sculptor. The dazzling summit of human achievement represented by Coppini lasted a little more than 40 years. But we must reckon the emergence of this artist as one of the greatest events in the art history of Texas. Monuments throughout the state recall his brilliance. His greatest work in Texas, the Alamo cenotaph (The Spirit of Sacrifice), reminds his beholders of the sacrifice made for the sake of the independence of Texas - a triumph of hope over experience. Texans would eventually prevail over their Mexican oppressors. The decisive battle of the war fought on April 21, 1836, and resulted in the creation of the Lone Star State. One is reminded of Gioacchino Rossini's opera, "William Tell” (1829), in which patriots secured the freedom of Switzerland from the tyranny of Austria. A eulogy written about Marcus Brutus, in William Shakespeare's play "Julius Caesar", applies to Coppini. "His life was gentle, and the elements So mixed in him that Nature might stand up And say to all the world "this was a man"”
(Shakespeare 1599). This case study suggests that art music can improve creativity and visual attention. The author recommends that music therapists explore this possibility through empirical studies.

\section{Notes}

* Coppini sang operatic arias to inspire his creative genius as a sculptor of monuments - the author.

1. Museo Nazionale Romano, Palazzo Massimo alle Terme, Largo di Villa Peretti, 1.

2. The operatic arias listed in this paper are based on the remembrance of Francisco Ruiz (1900-?), one of Coppini's assistants. Private interview was held at The Menger Hotel, 204 Alamo Plaza, San Antonio, Texas, June 2-4, 1976.

3. United States Census Reports, Volume I (Twelfth Census), 1901, clxxiv.

4. Munz, C. C. 1939. “Old Alamo Restored.” New York Times, November 19, Section XI.1. A cenotaph is a tomb or monument erected in honor of a person or persons whose bodies are interred elsewhere.

5. Coppini, P. 1949. From Dawn to Sunset. San Antonio, Texas: Naylor. Pp. 384-385. In 1954, Armistice Day became Veterans Day.

\section{References}

Belfiglio, V. J. 1995. The Italian Experience in Texas. Austin: Eakin Press.

Biesele, R. L. 1996. "Teich, Frank (1856-1939)." In The New Handbook of Texas, edited by R. Tyler. Austin: Texas State Historical Association.

Burson, L. N.d. Life and Works of Pompeo Coppini, Sculptor. San Antonio: Maverick-Clarke Litho Co.

Coppini, P. 1949. From Dawn to Sunset. San Antonio, Texas: Naylor.

Curlee, K. 1996. "Tauch, Waldine Amanda (1892-1986)." Pp. 212-213 in The New Handbook of Texas, edited by R. Tyler. Austin: The Texas State Historical Association.

Dallas Morning News. 1936. "Centennial Edition.” June 7, pp. 1-8.

Falk, P. H. 1985. Who Was Who in American Art. Madison, CT: Sound View Press.

Fehrenbach, T. R. 1985. Lone Star: A History of Texas and Texans. New York: Collier Books.

Forrester-O'Brien, E. 1935. Art and Artists of Texas. Dallas: Tardy.

Marquis, A. N., ed. 1940. Who's Who in America, 1940-1941. Chicago: A.N. Marquis Company. 
Munz, C. C. 1939. “Old Alamo Restored.” New York Times, November 19, Section XI.1.

Nancy, H. and A. Ramage. 1991. Roman Art: Romulus to Constantine. Englewood Cliffs, NJ: Prentice Hall.

Newsweek. 1940. "“Prettified', Alamo Memorial Tilts Noses in San Antonio." April 29, p. 41.

Pen, R. 1992. Introduction to Music. New York: McGraw-Hill.

Resasco, F. and S. Camposanto. 1922. Excursion Descriptive Illustre. Genoa, Italy: Tipografia Sociale.

Schoen, H., ed. 1938. Monuments Erected by the State of Texas to Commemorate the Centenary of Texas Independence. Austin: Commission of Control for Texas Centennial Celebrations.

Shakespeare, W. 1599. Julius Caesar. Act V, Scene 5.

Spivey, N. 2016. The Classical World. New York: Pegasus.
The Dallas Morning News. 1957. "Noted Italian Sculptor: Pompeo Coppini Dies." September 27, IV.15.

The Rotarian. 1939. "Coppini, Commemorator." October, p. 47.

White, J. T. 1965. The National Cyclopaedia of American Biography. Clifton, NJ: White.

\section{Bio}

Valentino Belfiglio, Ph.D., educator of international relations and diplomatic history, Department of History and Government, Texas Woman's University, Denton, Texas, USA; research fields: diplomatic history, women's studies, ancient Roman history. 